\title{
Evaluation of diagnostic accuracy of C-Reactive protein as a biomarker of spontaneous bacterial peritonitis in patients having decompensated chronic liver disease.
}

1. MBBS, FCPS (Gastroentrology)

Assistant

Professor Gastroenterology Pir Abdul Qadir Shah Jilani Institute of Medical Sciences Gambat.

2. MBBS, FCPS (Gastroentrology)

Senior Registrar Gastroenterology

Poonch Medical College Rawalakot Azad Kashmir.

3. MBBS, M.Phil (Biochemistry) Assistant Professor Biochemistry Bahria University Medical and Dental College.

4. MBBS, FCPS (Internal Medicine) Assistant Professor Medicine Ghulam Mohammad Mahar Medical College Sukhur.

5. MBBS, FCPS (Gastroentrology) Senior Registrar Medicine and Allied Bahria University Medical and Dental College.

6. MBBS, M.Phil (Biochemistry) Senior Lecturer Biochemistry Jinnah Sindh Medical University, Karachi Pakistan.

Correspondence Address:

Dr. Sadia Rehman

Department of Biochemistry

Bahria University Medical and Dental College.

dr.sadia89@hotmail.com

Article received on:

07/01/2021

Accepted for publication:

25/03/2021

\section{INTRODUCTION}

Ascitic fluid infection (AFI) is the most commonly occurring complication in patients having decompensated liver disease. ${ }^{1} \mathrm{AFI}$ acts as a trigger for the development of other complications of cirrhotic liver disease which include variceal bleeding, hepatic encephalopathy and hepatorenal syndrome. AFI is of two type's culture-negative neutrocytic ascites (CNNA) and spontaneous bacterial peritonitis. ${ }^{2}$ The in-hospital mortality rate is much higher in SBP patients than those with culture-negative neutrocytic ascites. Prompt detection and early initiation of antibiotic therapy are crucial for the better outcome of treatment in patients with SBP. ${ }^{3}$ Early stage of SBP is difficult to detect. Culture examination of ascitic fluid takes 24-48 hours which causes a delay in the diagnosis and initiation of treatment. ${ }^{4}$ Hence, for the early diagnosis of SBP the evaluation of clinical and laboratory parameters are of great clinical importance. SBP is an ascitic fluid infection without any surgically treatable intra-abdominal cause. SBP is diagnosed by a positive bacterial culture of the ascitic fluid and an elevated ascitic fluid polymorphonuclear leukocyte (PMN) count $(\geq 250$ cells $/ \mathrm{mm} 3){ }^{5}$ Elevated ascitic fluid PMN count is enough to make a preliminary diagnosis of SBP and put the patient on antibiotic therapy. ${ }^{6}$ If the paracentesis is performed after initiation of the antibiotic therapy, then the culture mostly gives negative result. ${ }^{7}$

An accurate diagnosis of cause is essential for successful treatment of ascites. Liver cirrhosis is the cause of approximately 80 percent of the cases of ascities in the United States. The patients 
having ascities due to liver disorder usually give a good response to sodium restriction and diuretics. $^{8}$

C-Reactive protein is an acute phase inflammatory protein present in the serum. ${ }^{9} \mathrm{CRP}$ is produced by liver and vascular endothelial cells. ${ }^{10}$ Elevated levels of CRP indicates the ongoing inflammatory process, and the absence of a high CRP level indicates the exclusion of infection or inflammation. CRP may also be used as an assessment biomarker of inflammatory changes in response to treatment. ${ }^{11,12}$

Traditionally, suspected intra-peritoneal bacterial infections in patients with decompensated chronic liver disease were evaluated by evaluation of the ascitic fluid. Neutrophils count was taken as $>250$ cells $/ \mathrm{mm} 3$ as the gold standard for the diagnosis of SBP. ${ }^{13}$

For immediate diagnosis of the presence of ascitic fluid infections in decompensated liver disease patients, reliable biomarkers are necessary. The biomarkers like CRP and pro-calcitonin are helpful in the diagnosis of SBP. ${ }^{14}$ Diagnosis at an early stage and early initiation of treatment are essential for good prognosis of SBP. The first stage of the disease is difficult to determine in cases of bacterial infection. ${ }^{15,16}$ Hence the evaluation of these biomarkers is of great clinical importance.

We planned this study to evaluate the role CRP in the detection of SBP in patients having decompensated chronic liver disease. This study will help the gastroenterologists in the identification of early diagnostic biomarkers of this disease and hence improve the treatment outcome of these patients.

\section{MATERIAL \& METHODS}

This study was a cross sectional study which was conducted from 01-02-2018 to 20-12-2018 at Department of Medicine Sheikh Khalifa Bin Zayed Hospital Rawalakot Azad Kashmir.

With the help of WHO calculator a sample size of 186 subjects was calculated.
Consecutive Non probability sampling technique was used. Inclusion criteria was adult patients (age $>18$ to $<75$ years) presenting with decompensated chronic liver disease. Exclusion criteria was Decompensated chronic liver disease patients with absence of ascites as determined by an abdominal ultrasound and evidence of infection from other sources as evident by urine and stool routine examination, chest $x$-ray or obvious source of skin infection.

This study was approved by the ethical review board (PMC-RKT/520/2019). Confidentiality of the patients was ensured. SPSS (version 21) was used to enter and analyze the data. Mean \pm standard deviation (SD) of the quantitative variables were calculated. For qualitative variables frequencies and percentages were calculated.

The objective of the present research was to determine the diagnostic accuracy of CRP for evaluation of SBP in patients with decompensated chronic liver disease keeping asicitic fluid neutrophilic count more than $250 / \mathrm{mm}^{3}$ as a gold standard.

\section{RESULTS}

In this regard we collected data from one hundred and eighty six (186) patients having decompensated chronic liver disease. The minimum age was found as 21 years and maximum age was 75 years with mean + standard deviation $43.36+13.68$ years. The minimum neutrophil count in ascitic fluid was found as $45 / \mathrm{mm}^{3}$ and maximum neutrophil count was $255 / \mathrm{mm}^{3}$ with mean + standard deviation $794.60+1032.53$ $/ \mathrm{mm}^{3}$. The minimum CRP level was found as 5 $\mathrm{mg} / \mathrm{L}$ and maximum CRP level was $160 \mathrm{mg} / \mathrm{L}$ with mean + standard deviation $52.42+60.66 \mathrm{mg} / \mathrm{L}$. There were 104 (55.59\%) male patients and 82 (44.41\%) female patients. Spontaneous bacterial peritonitis was present in 61 (32.8\%) patients of decompensated chronic liver disease and $125(67.2 \%)$ patients were without spontaneous bacterial peritonitis. There were 67 (36\%) patients in which CRP levels was greater than $29.5 \mathrm{mg} / \mathrm{L}$ and there were 119 (64\%) patients in which CRP levels was less than $29.5 \mathrm{mg} / \mathrm{L}$. 
For evaluation of diagnostic accuracy of CRP in SBP in patients with chronic liver disease, we calculated sensitivity, specificity, positive predictive value and negative predictive value. The sensitivity was calculated as $83.61 \%$, specificity was calculated as $87.2 \%$, positive predictive value was $76.12 \%$, negative predictive value was $91.59 \%$ and diagnostic accuracy was observed from the collected data as $86.02 \%$.

Sensitivity, specificity, Positive predictive value (PPV) and Negative prediction value (NPV) were calculated according to the following Table-I.

\begin{tabular}{|l|c|c|}
\hline & SBP Present & SBP Absent \\
\hline CRP levels $\geq 29.5 \mathrm{mg} / \mathrm{L}$ & $\mathrm{a}(\mathrm{TP})$ & $\mathrm{b}(\mathrm{FP})$ \\
\hline CRP levels $<29.5 \mathrm{mg} / \mathrm{L}$ & $\mathrm{c}(\mathrm{FN})$ & $\mathrm{d}(\mathrm{TN})$ \\
\hline \multicolumn{2}{|c|}{ Table-I. Diagnostic accuracy of CRP for evaluation of } \\
SBP.
\end{tabular}

CRP: C-reactive protein; SBP: Spontaneous Bacterial Peritonitis

$\begin{array}{ll}\text { TP: } & \text { True positive } \\ \text { TN: } & \text { True negative } \\ \text { FP: } & \text { False positive } \\ \text { FN: } & \text { False negative }\end{array}$

Sensitivity: $\quad a / a+c \times 100$

Specificity: $\quad d / b+d \times 100$

PPV:

$b / a+b \times 100$

NPV:

$\mathrm{d} / \mathrm{c}+\mathrm{d} \times 100$

DA:

$a+d / a+b+c+d \times 100$

\begin{tabular}{|l|c|c|c|c|}
\hline & Minimum & Maximum & Mean & $\begin{array}{c}\text { Std. } \\
\text { Deviation }\end{array}$ \\
\hline Age & 20 & 75 & 43.36 & 13.68 \\
\hline $\begin{array}{l}\text { Neutrophil } \\
\text { Count in ascitic } \\
\text { fluid }\end{array}$ & 45 & 2550 & 794.60 & 1032.53 \\
\hline CRP Level & 5 & 160 & 52.42 & 60.66 \\
\hline
\end{tabular}

Table-II. Descriptive statistics.

\begin{tabular}{|l|c|c|}
\hline & Frequency & Percentage \\
\hline Yes & 67 & $36 \%$ \\
\hline No & 119 & $64 \%$ \\
\hline Total & 186 & 100.0 \\
\hline
\end{tabular}

Table-III. Frequency and percentage of CRP Level > $29.5 \mathrm{mg} / \mathrm{L}$.

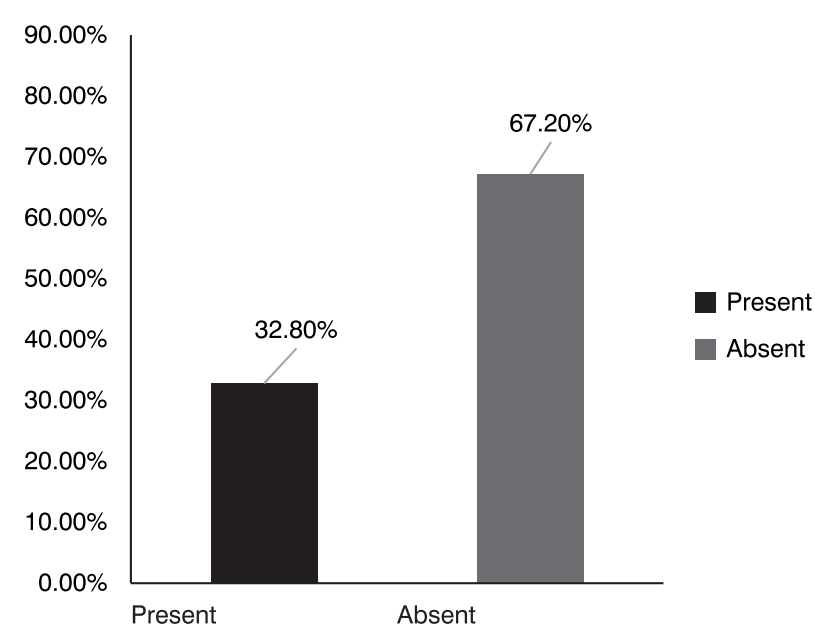

Figure-1. Bar Chart of presence of SBP.

\begin{tabular}{|l|c|c|c|c|}
\hline \multicolumn{2}{|c|}{} & \multicolumn{2}{c|}{$\begin{array}{c}\text { Spontaneous } \\
\text { Bacterial Peritonitis }\end{array}$} & \multirow{2}{*}{ Total } \\
\cline { 2 - 4 } & Present & Absent & \\
\hline $\begin{array}{l}\text { CRP Level }> \\
\text { 29.5mg/L }\end{array}$ & Yes & 51 & 16 & 67 \\
\hline No & 10 & 109 & 119 \\
\hline Total & 61 & 125 & 186 \\
\hline \multicolumn{2}{|c|}{ Table-IV. 2x2 table of CRP Levels > 29.5mg/L and } \\
SBP.
\end{tabular}

Sensitivity: $\quad \frac{\mathrm{a}}{\mathrm{a}+\mathrm{c}} \times 100=83.61 \%$

Specificity: $\quad \frac{\mathrm{d}}{\mathrm{d}+\mathrm{b}} \times 100=87.2 \%$

Positive Predictive Value: $\frac{\mathrm{a}}{\mathrm{a}+\mathrm{b}} \times 100=76.12 \%$

Negative Predictive Value: $\frac{\mathrm{d}}{\mathrm{d}+\mathrm{c}} \times 100=91.59 \%$

Diagnostic Accuracy: $\frac{a+d}{a+b+c+d} \times 100=86.02 \%$

\section{DISCUSSION}

We collected data from one hundred and eighty six patient having decompensated chronic liver disease. In 186 patients, the age of the patients was between 20 years and 75 years. There were $55.59 \%$ male and $44.41 \%$ female subjects suffering from chronic liver disease. The minimum neutrophil count found in the ascitic fluid was found as $45 / \mathrm{mm}^{3}$ and the maximum neutrophil count was $2550 / \mathrm{mm}^{3}$ with mean + standard deviation $794.60+1032.53 / \mathrm{mm}^{3}$. The minimum level of CRP in our study subjects was found as 5 $\mathrm{mg} / \mathrm{L}$ and the maximum level was $160 \mathrm{mg} / \mathrm{L}$ with mean + standard deviation $52.42+60.66 \mathrm{mg} / \mathrm{L}$. 
Deutsch et $\mathrm{al}^{17}$ in their article have discussed the characteristics of bacterial infections in cirrhotic liver disease patients and the role of CRP. Their results are similar to the findings of our study. In our study SBP was detected among 32.8\% subjects of decompensated chronic liver disease while $67.2 \%$ of the study subjects were without SBP. In $36 \%$ subjects CRP level was found to be $>29.5 \mathrm{mg} / \mathrm{L}$ and in $64 \%$ subjects CRP level was < $29.5 \mathrm{mg} / \mathrm{L}$.

According to our study the sensitivity of CRP in diagnosing SBP was calculated as $83.61 \%$ while the specificity of CRP was calculated as $87.2 \%$. The positive predictive value was $76.12 \%$ while the negative predictive value was $91.59 \%$. The diagnostic accuracy of CRP as calculated from the collected data was $86.02 \%$. Ashour et $\mathrm{al}^{18}$ and Khedher et $\mathrm{al}^{19}$ in their studies have also shown that CRP is a good diagnostic and prognostic biomarker in cases of SBP in cirrhotic liver disease.

Lazzarotto et $\mathrm{al}^{20}$ showed that CRP level of $\geq$ $29.5 \mathrm{mg} / \mathrm{L}$ is $81 \%$ accurate for diagnosis of SBP in patients presenting with acute decompensated chronic liver disease with a sensitivity and specificity of $82 \%$. The results from our study and those from previous studies shown that CRP has a good diagnostic and prognostic accuracy in detecting SBP in patients suffering from chronic liver disease.

\section{CONCLUSION}

A CRP level of $\geq 29.5 \mathrm{mg} / \mathrm{L}$ gave $86.02 \%$ accuracy for the diagnosis of spontaneous bacterial peritonitis in patients presenting with decompensated chronic liver disease. So CRP is reliable for the diagnosis of bacterial infections in ascitic patients having chronic liver disease.

Copyright@ 25 Mar, 2021.

\section{REFERENCES}

1. Farooq $A A$, Farooq $A$, Rashid $M$, Farooq JH, Umbreen $S$, Waseem R. Association of portal vein doppler parameters with chronic liver disease child pugh classes: A single center experience at Rawalpindi, Pakistan. Journal of Islamic International Medical College Quarterly::33.
2. Amr S, Ahmed AR, Hoda E. Spontaneous bacterial peritonitis: An overview. Medical Journal of Viral Hepatitis. 2018 Nov 1; 3(1):13-7.

3. Estakhri R, Bartari L, Ghojazadeh M. Diagnostic value of serum procalcitonin level in the diagnosis of the spontaneous bacterial peritonitis. Immunopathologia Persa. 2020 May 4; 6(2):e19-.

4. Galal GM, Elsharkawy R, Sayed SA, Alkadi M. Predictors of ascetic fluid infection in cirrhotic patients. Sohag Medical Journal. 2019 Jan 1; 23(1):6-10.

5. Hua $Y$, Zhao C, Min LI, Jin Y, Zhao $Y$, Wang $H$. The significance of serum procalcitonin and $\mathrm{C}$-reactive protein in the diagnosis of spontaneous bacterial peritonitis in patients with liver cirrhosis combined with ascites. Chinese Journal of Postgraduates of Medicine. 2017 Jan 1; 40(11):986-9.

6. Kadam N, Acharya S, Shukla S, Gupta K. Ascitic fluid high sensitive C-reactive protein (hs-CRP). A prognostic marker in cirrhosis with spontaneous bacterial peritonitis. Journal of Clinical and Diagnostic Research: JCDR. 2016 Apr; 10(4):OC20.

7. Lutz P, Goeser F, Kaczmarek DJ, Schlabe S, Nischalke HD, Nattermann J, Hoerauf A, Strassburg CP, Spengler $U$. Relative ascites polymorphonuclear cell count indicates bacterascites and risk of spontaneous bacterial peritonitis. Digestive Diseases and Sciences. 2017 Sep 1; 62(9):2558-68.

8. Ma LN, Liu XY, Lu ZH, Wu LG, Tang YY, Luo X, Hu YC, Yan TT, Wang Q, Ding XC, Xie Y. Assessment of highsensitivity $\mathrm{C}$-reactive protein tests for the diagnosis of hepatocellular carcinoma in patients with hepatitis B-associated liver cirrhosis. Oncology Letters. 2017 May 1; 13(5):3457-64.

9. Mattos AA, Wiltgen D, Jotz RF, Dornelles CM, Fernandes MV, Mattos ÂZ. Spontaneous bacterial peritonitis and extraperitoneal infections in patients with cirrhosis. Annals of Hepatology. 2020 Sep 1; 19(5):451-7.

10. Metwally K, Fouad T, Assem M, Abdelsameea E, Yousery M. Predictors of spontaneous bacterial peritonitis in patients with cirrhotic ascites. Journal of Clinical and Translational Hepatology. 2018 Dec 28; 6(4):372.

11. Mousa N, Besheer T, Abdel-Razik A, Hamed M, Deiab AG, Sheta T, Eldars W. Can combined blood neutrophil to lymphocyte ratio and C-reactive protein be used for diagnosis of spontaneous bacterial peritonitis?. British journal of biomedical science. 2018 Apr 3; 75(2):71-5. 
12. Munir A, Jehangir A, Ayub F. Hepatoprotective Effect of Aqueous Extract of Cichorium Intybus (Kasni) on Pyrazinamide Induced Hepatotoxicity in Male Mice. Journal of Islamic International Medical College Quarterly.:72.

13. Raza SA, Clifford GM, Franceschi S. Worldwide variation in the relative importance of hepatitis $C$ viruses in hepatocellular carcinoma: A systematic review. Br J Cancer 2007; 96:1127-34.

14. Rizk E, Elzehery R, Zakaria S, Abdel-Razik A, Elhammady D. Ascitic fluid calprotectin and serum C-reactive protein as diagnostic markers for spontaneous bacterial peritonitis. Afro-Egyptian Journal of Infectious and Endemic Diseases. 2014 Sep 20; 4(3):117-25.

15. Shizuma T. Spontaneous bacterial and fungal peritonitis in patients with liver cirrhosis: A literature review. World journal of hepatology. 2018 Feb 27; 10(2):254.

16. Sproston NR, Ashworth JJ. Role of C-reactive protein at sites of inflammation and infection. Frontiers in immunology. 2018 Apr 13; 9:754.
17. Deutsch M, Manolakopoulos S, Andreadis I, Giannaris M, Kontos G, Kranidioti H, Pirounaki M, Koskinas J. Bacterial infections in patients with liver cirrhosis: Clinical characteristics and the role of $\mathrm{C}$-reactive protein. Annals of gastroenterology. 2018 Jan; 31(1):77.

18. Ashour MA, Elsaid HH, Gomaa AF, Mahmoud AA. Serum and ascitic fluid high sensitive $C$ reactive protein as prognostic marker in patients with spontaneous bacterial peritonitis. Zagazig University Medical Journal. 2019 May 1; 25(3):317-25.

19. Khedher S, Fouthaili N, Maoui A, Lahiani S, Salem M, Bouzid $K$. The diagnostic and prognostic values of $\mathbf{C}$ - reactive protein and procalcitonin during bacterial infections in decompensated cirrhosis. Gastroenterology Research and Practice. 2018 Dec 30; 2018.

20. Lazzarotto C, Ronsoni MF, Fayad L, Nogueira CL, Bazzo ML, Narciso-Schiavon JL, de Lucca Schiavon L, DantasCorrêa EB. Acute phase proteins for the diagnosis of bacterial infection and prediction of mortality in acute complications of cirrhosis. Annals of hepatology. 2013 Jul 15; 12(4):431-9.

\begin{tabular}{|c|c|c|c|}
\hline \multicolumn{4}{|c|}{ AUTHORSHIP AND CONTRIBUTION DECLARATION } \\
\hline Sr. \# & Author(s) Full Name & Contribution to the paper & Author(s) Signature \\
\hline 1 & Kapeel Raja & Main researcher. & \\
\hline 2 & Rizwan Saeed Kiyani & $\begin{array}{l}\text { Data collection and final } \\
\text { approval. }\end{array}$ & \\
\hline 3 & Sadia Rehman & $\begin{array}{l}\text { Literature review and write } \\
\text { up. }\end{array}$ & \\
\hline 4 & Abdul Rashid & Data analysis. & \\
\hline 5 & Sanjay Kumar & Drafting of work. & \\
\hline 6 & Anila Bibi & Data collection. & \\
\hline
\end{tabular}

